Vol. 3, No. 01; 2020

ISSN: 2581-4664

\title{
DETERMINANT OF JOB SATISFACTION AND EMPLOYEE PERFORMANCE : STUDY IN HOUSE OF REPRESENTATIVE (DPRK) SECRETARIAT OF PIDIE JAYA
}

\author{
*Fakhrurrazi, Said Musnadi and Teuku Roli Ilhamsyah Putra
}

Department of Management, Universitas Syiah Kuala, Indonesia

http://doi.org/10.35409/IJBMER.2020.3154

\begin{abstract}
The purpose of this study is know the effect of competence, organizational culture, and reward, on job satisfaction and and employee performance. This research is conducted at the House Of Representative (DPRK) secretariat of Pidie Jaya. The population is all its as much as 151, consisting of 131 civil servants and 20 contract workers. Sampling is taken by census technique and it provides 151 people as respondents. Data analysis tool used in this study is Structural Equation Model (SEM) with the help of the Amos program. The result shows that competence effects employee performance significantly, organizational culture effects employee performance significantly, reward effects employee performance significantly, competence effects job satisfaction significantly, organizational culture effects job satisfaction significantly, reward effects job satisfaction significantly, and job satisfaction effects the employee performance significantly. The originality lies in the integration of the model from previous ones, the timeline and the object. This also has an approach in testing the model using SEM. The findings has an implication to the realm of science in completing the causality theories, and enrich the knowledge. Also this can be as a reference for the further research in developing the new models. Beside, the result is useful for the practical managers especially the leader in DPRK Secretariat of Pidie Jaya. The variables related figure the points that need to be improved and strengthened for the better employee performance
\end{abstract}

Keyword: competence, organizational culture, reward, job satisfaction and employee performance.

\section{INTRODUCTION}

The House of representative (DPRK) of Pidie Jaya has a vision that is "Become a trusted representative institution and able to create political stability and a healthy democratic climate to support the realization of Pidie Jaya society that is prosperous, fair, insightful and religious environment". In the implementation, the basic tasks and the function of the senators in DPRK are according to the established organizational structure, supported by the availability of institutional facilities and infrastructure, standard system of procedures and the number of employees and the provision of adequate budgets. DPRK is supported by its secretariat institution, that take care their administrative matters and the other needs of senators. to These supporting factors can play a positive role if potential human resource can be used maximally 


\section{International Journal of Business Management and Economic Review}

Vol. 3, No. 01; 2020

ISSN: 2581-4664

and the use of funds effectively and efficiently.

As the executing apparatus of the organization, quality of human resources and adequate management facilities are very needed for the development of human resources. Human resources owned so far have not been well developed. There is even a tendency that the bureaucracy lacks understandings of the relationship between economic development processes and human resource development. In such circumstances, it gives the impression of being indifferent and lacking impartiality to pay attention to the issue of organization empowerment through empowering human resources, especially when it comes to the quality of human resources, which influence on the performance of the DPRK secretariat staffs. According to (Timpe, 2012), performance is the level of achievement of a person or employee in an organization or company that can increase productivity. According to Meiner (2012) performance is a success that can be achieved by individuals in doing their work, where the measure of success achieved by individuals can not be equated with other individuals. The success achieved by an individual is based on the applicable size and adjusted to the type of work. Then Subowo (2012) states that performance is closely related to goals or as a result of individual work behavior, the expected results can be demands of the individual itself. employee performance according to (Siagan, 2012) is an overall ability of a person to work in such a way as to achieve work goals optimally and various targets that have been created with sacrifices that the ratio is smaller than the results achieved .

(Azwar, Darsono and Djalil, 2017) research's proved that job satisfaction felt by employees has an influence on employee performance. It indicates that the existence of job satisfaction felt by employees will have an impact on improving employee performance. Employee job satisfaction at The House of representative (DPRK) Secretariat of Pidie Jaya is a very important factor to obtain optimal result. job satisfaction is something that every employee carves because in every agency human resource factor is a very decisive element. it determines the achievement of effective agency goals and efficient. Every employee of the agency will devote their power and thought in order to increase work productivity if they are satisfied at their job. (Furnham et al., 2005) defines job satisfaction as the degree of which they are satisfied with their work. (Sopiah, 2008) explains job satisfaction is a person's emotional response to work situations and conditions. Emotional responses can be in the form of feeling satisfied (positive) or dissatisfied (negative). (Soetrisno, 2009) states that job satisfaction is an employee's attitude towards work related to work situations, cooperation between employees, rewards received at work, and matters relating to physical and psychological factors. This attitude towards work is the result of a number of special attitudes of individuals and social relations outside of work so that it raises the general attitude of the individual towards the work he faces. (Bhuian and Menguc, 2002) in (Boles et al., 2007) describes job satisfaction is defined as the attitude that individuals have about their work. That is the extent to which people feel positive or negative about the intrinsic and / or extrinsic aspects of a job. (Mangkunegara, 2010) stated that job satisfaction is the difference between expectations imagined by someone from the contribution of work that has been done to the reality they expect. From some of the above opinions it can be concluded that job satisfaction is someone's response to what they expect when working with what they get after they do the work. It can be related to the work situation, cooperation between employees, benefits and other factors. If there is a small difference between what is expected and what is obtained then that person will feel satisfied and vice versa. 


\section{International Journal of Business Management and Economic Review}

Vol. 3, No. 01; 2020

ISSN: 2581-4664

Human resources is one of the factors that determine the achievement of targets in carrying out all activities. Human resources are also a prime mover or innovator to carry out its function in government agencies or companies. Problem faced by the DPRK secretariat lies in the institution that is still powerless in managing human resources efficiently in achieving organizational goals. The low ability of employees to carry out their duties and functions, its related to the limited quality of human resources and government management facilities. According to (Wibowo, 2013), organization is formed to achieve certain goals and if it is achieved then be referred to as a success . To achieve success, a strong foundation is needed in the form of leadership competence, employee competence and work discipline that can strengthen and maximize competence. Competencies become very useful to help organizations create a culture of high performance, work performance in every process of human resources, employee selection, performance management, planning and so on. According to (Hartati, 2005), competence is the ability to carry out tasks in accordance with science and skills as well as technology and experience relevant to the task field so as to develop work motivation and performance improvement. Along with the increasingly intense competition in the business world as a result of economic liberalization in various industrial sectors today, the role of human resources as the main determining factor of whether a company is able to compete dynamically and profitably is increasingly felt its importance. The competitive advantage of an organization is largely determined by the quality of its human resources. HR management must be carried out thoroughly within the framework of a strategic, integrated, interrelated and unity HR management system. Organizations really need competent human resources, have certain competencies needed to support the successful implementation of their work .

Improvement or empowerment of human resources in a company continues to be done through programs such as training and development of employees, assessment, and installation of the Human Resources Information System program . However, it is often felt that it is not yet provided optimal results for the empowerment and development of the quality of the human resources themselves. It is because improvements or empowerment in the field of human resources are often carried out without being based on a strategic grand scenario.

While relating to the rewards given to each employee as a form of reward for the efforts made so far, it also contributes to increasing job satisfaction and employee performance. reward is also one of the factors that can have an influence on improving employee performance and organizational performance. Someone will be strongly motivated if the interests of the employee are fulfilled. One of the employee's individual interests will be fulfilled by the rewards they receive, in return for their work. The definition of reward according to (Edirisooriya, 2014) reward is the benefit received to perform tasks. It's a positive stimulus or incentive that can be presented in the process of strengthening behavior. This consideration in work arrangements is called employee benefits. reward benefit is a leadership program to use and to supplement cash compensation received by employees.

The results can be extrinsic or intrinsic. Extrinsic rewards are tangible rewards from the employer. External rewards can be in terms of salary / wages, incentives, bonuses, stock options, promotions, job security, intrinsic rewards are tangible rewards or psychological rewards that one receives from the work itself. It called as self-starting rewards. Pride such as work-in-one's feelings of achievement, appreciation, meeting new challenges, positive and caring attitudes from employers, participation in decision making, or being part of a team. rewards may or may 


\section{International Journal of Business Management and Economic Review}

Vol. 3, No. 01; 2020

ISSN: 2581-4664

not improve employee financial well-being.

According to (Nawawi, 2011) stated that reward for an organization or company means appreciation and reward to workers who have contributed in realizing their goals, through activities called work.

The understanding according to (Dessler, 2003) in (Yuniarsih, 2009), says that employee rewards mean all forms of payroll or rewards that flow to employees or arise from their staffing. (William B. Werther and Davis, 1996) in (Yuniarsih, 2009), defines reward as what is received by an employee as a substitute for the contribution he/she makes to the organization.

Another variable that is indicated as the causality of the problem occurs is about its organizational culture. organizational culture can be described specifically in relation to the way people think, which leads to how they act. As expressed by experts, (Schein, 1996) that, "Culture manifests in terms of behavior and espoused values that the essence of culture lies in the set of underlying assumptions".

Similarly (Deshpandé, Farley and Webster, 1993), defined that "Organizational culture as a set of shared assumption and understanding about organization functioning". And in theory about culture that is "Culture is that it is a complex system of norms and values that is shaped over time" . Every organization has an unwritten culture that defines standards of behavior that are well accepted and not for employees.

While organizational culture according to (J. Peters and H. Waterman, 1982), organizational culture is a pattern of basic assumptions found, created, or developed by a particular group with the intention that the organization learns to overcome the problems that arise due to external adaptation and internal integration that has been going well enough, so, it needs to be taught to new members as a correct way to understand, think about and feel about these problems. (Shahzad et al., 2012) explains that organizational culture is a form of reference for interaction of members of the organization and a form of reference for interaction with outside parties. Meanwhile, according to (Robbins and Judge, 2012) of organizational culture is thr perception jointly held by members of the organization.

From discussion above, the research model and hypothesis for this research show as follows.

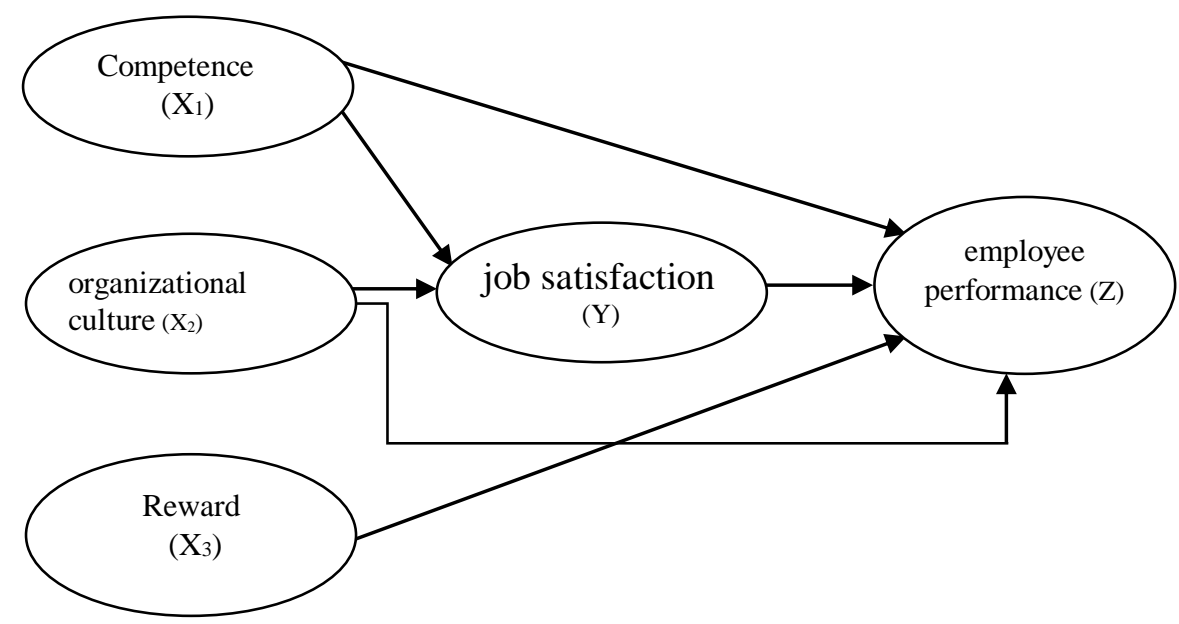

Figure 1. Research Paradigm 
Vol. 3, No. 01; 2020

ISSN: 2581-4664

H1 ; competence effects employee performance significantly

$\mathrm{H} 2$ : organizational culture effects employee performance significantly

H3 : reward effects employee performance significantly

$\mathrm{H} 4$ : competence effects job satisfaction significantly

H5 : organizational culture effects job satisfaction significantly

H6 : reward effects job satisfaction significantly

H7 : job satisfaction effects employee performance significantly

\section{METHOD}

This is the verification research that test the causalities among variables, based form the previous theories. This research is conducted at the DPRK Secretariat of Pidie Jaya. The population is all its as much as 151, consisting of 131 civil servants and 20 contract workers. Sampling is taken by census technique and it provides 151 people as respondents. Authors build constructs to measure each variable in this research, that are : 1. competence : Level of knowledge, Work ability, Communication skills, Skills, IT Mastery, and Attitude attitude; 2. organizational culture : Innovation and risk taking, Attention to details, Orientation of results, Team orientation, Aggressiveness, and Stability; 3. reward : salary, incentives, Allowances, facilities, and work performance allowance (TPK); 4. job satisfaction : compensation, promotion, teamwork, supervisor, and work; 5. employee performance : Quality of work, Work quantity, Timeliness, Work effectiveness, Independence, Work commitment.

Personal questionnaires are used to obtain data about the dimensions / constructs that are being developed. Likerd is used as a scale to measure the constructs. Data analysis tool used in this study is Structural Equation Model (SEM) with the help of the Amos program. The SEM equation model is a collection of statistical techniques that allow the simultaneous testing of a series of relatively complex relationships (Ferdinand, 2006). SEM is able to enter latent variables into the analysis. Latent variables are unobserved concepts that are approximated by observable or measured variables obtained by respondents through data collection methods (surveys, tests, observations) and are often called manifest variables (Latan and Ghozali, 2012).

\section{RESULTS}

The analysis is a full model Structural Equation Model (SEM) analysis, after the analysis of the dimensionality level of the indicators forming latent variables tested with confirmatory factor analysis. Analysis of data processing results in the full SEM model stage is carried out by conducting a suitability test and a statistical test. The result of data processing for the full SEM model analysis is shown in figure below. 
International Journal of Business Management and Economic Review

Vol. 3, No. 01; 2020

ISSN: 2581-4664

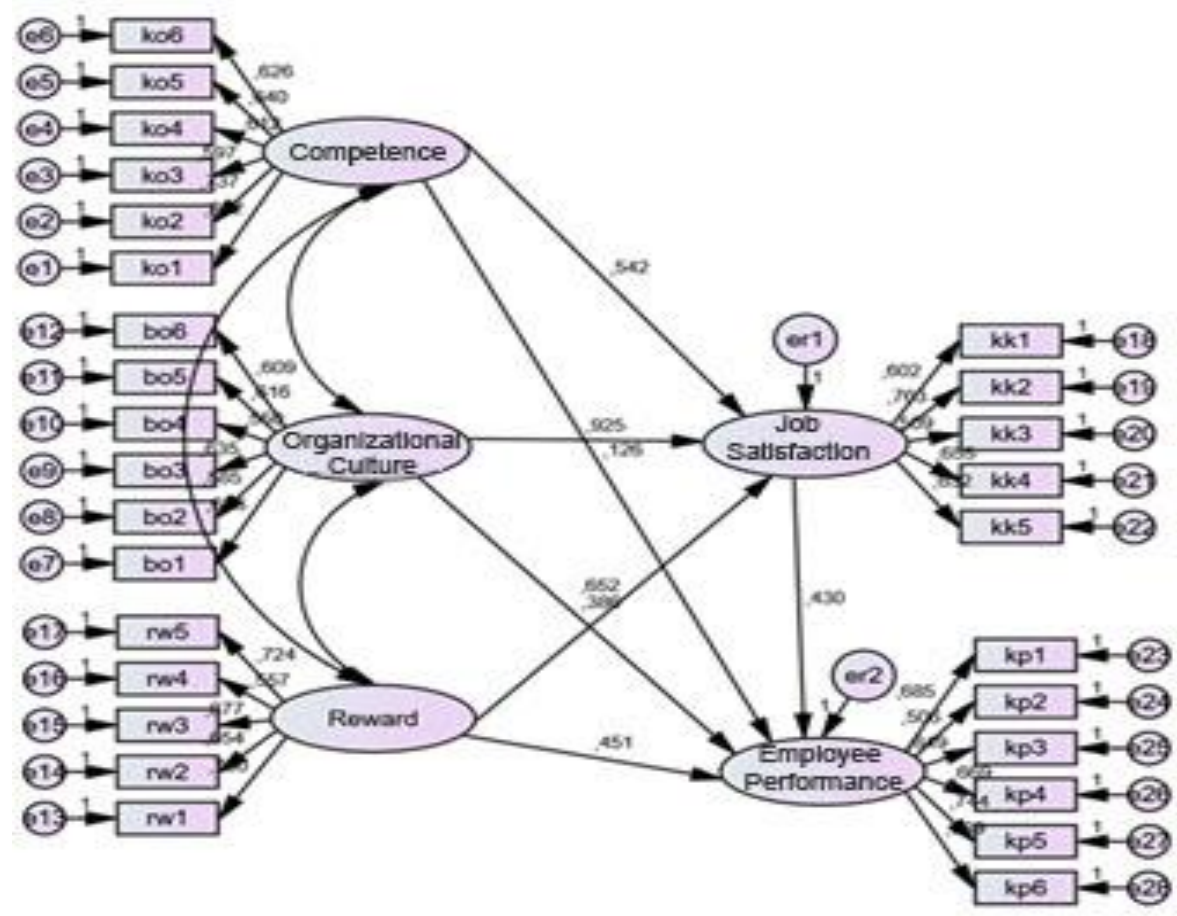

Figure 2. Structural Model

Based on Figure 2 , the 7 hypotheses of this research is carried out based on the Critical Ratio (CR) value of a causal relationship from the results of SEM processing as in the following table.

Tabel 1. Regression Weight

\begin{tabular}{|c|c|c|c|c|c|}
\hline & & Estimate & Standardized Regrssion & C.R & $\mathrm{P}$ \\
\hline $\begin{array}{l}\text { Employee } \\
\text { Performance }\end{array}$ & <--- Competence & 0,126 & 0,049 & 2,571 & $* * *$ \\
\hline $\begin{array}{l}\text { Employee } \\
\text { Performance }\end{array}$ & $\begin{array}{ll}--- & \text { Organizational } \\
& \text { Culture }\end{array}$ & 0,386 & 0,158 & 2,443 & $* * *$ \\
\hline $\begin{array}{l}\text { Employee } \\
\text { Performance }\end{array}$ & <--- Reward & 0,451 & 0,142 & 3,176 & $* * *$ \\
\hline $\begin{array}{l}\text { Employee } \\
\text { Performance }\end{array}$ & $<---\quad$ Job Satisfaction & 0,430 & 0,143 & 3,007 & $* * *$ \\
\hline $\begin{array}{l}\text { Job } \\
\text { Satisfaction }\end{array}$ & $<---\quad$ Competence & 0,542 & 0,078 & 6,949 & $* * *$ \\
\hline $\begin{array}{l}\text { Job } \\
\text { Satisfaction }\end{array}$ & $\begin{array}{ll}<--- & \text { Organizational } \\
& \text { Culture } \\
\end{array}$ & 0,925 & 0,159 & 5,818 & $* * *$ \\
\hline $\begin{array}{l}\text { Job } \\
\text { Satisfaction }\end{array}$ & <--- Reward & 0,652 & 0,097 & 6,722 & $* * *$ \\
\hline
\end{tabular}




\section{International Journal of Business Management and Economic Review}

Vol. 3, No. 01; 2020

ISSN: 2581-4664

H1 (accepted) : The effect of competence on employee performance

The estimated parameter for testing the effect of competence on employee performance obtained a CR value of 2.571. Thus it explains that competence effects performance of employees significantly .

$\mathrm{H} 2$ (accepted) : The effect of organizational culture on employee performance

The influence of organizational culture on employee performance obtained a CR value of 2.443 which is greater than 1.97 and a probability smaller than 0.05 . Thus it describes that the organizational culture effects employee performance significantly .

H3 (accepted): The Effect of reward on employee performance

The effect of reward on employee performance with a $\mathrm{CR}$ value of 3.176 which is greater than 1.97 and a probability smaller than 0.05 . Thus it concludes that the reward effects employee performance significantly .

H4 (accepted) : The effect of competence on job satisfaction

The effect of competence on job satisfaction is obtained a CR value of 6.949 which is greater than 1.97 and a probability smaller than 0.05 . Thus it figures that competence influences job satisfaction significantly. This indicates that the higher level of competency possessed by employees will have a positive and real impact on increasing job satisfaction due to the involvement of all employees in carrying out work so that it can help in completing work of every employees.

H5 (accepted) : The effect of organizational culture on job satisfaction

The influence of organizational culture on job satisfaction with a CR value of 5.818 which is greater than 1.97 and a probability smaller than 0.05 . Thus it defines that the organizational culture effects job satisfaction significantly.

H6 (accepted) : The effect of reward on job satisfaction

The estimated parameter for testing the effect of reward on employee job satisfaction shows a CR value of 6.722 and with a probability of 0,000 . Both of the values obtained are eligible for $\mathrm{H} 3$ acceptance, namely a CR value of 6.722 which is greater than 1.97 and a probability smaller than 0.05 . Thus it figures that the reward effects job satisfaction significantly.

H7 (accepted) : The effect of job satisfaction on employee performance

The influence of job satisfaction on employee performance is obtained by a CR value of 3.007 which is greater than 1.97 and a probability smaller than 0.05 . Thus it says that job satisfaction effects the employee performance significantly.

The implication of this research lies to how the organization teats the employee. The higher level of satisfaction generated by employees will have a good influence in improving the performance of Pidie Jaya District Secretariat Office employees. 


\section{International Journal of Business Management and Economic Review}

Vol. 3, No. 01; 2020

ISSN: 2581-4664

\section{CONCLUSIONS}

The result shows that competence effects employee performance significantly, organizational culture effects employee performance significantly, reward effects employee performance significantly, competence effects job satisfaction significantly, organizational culture effects job satisfaction significantly, reward effects job satisfaction significantly, and job satisfaction effects the employee performance significantly. The originality of this research lies in the integration of the research model from previous ones, the time and the object. This also has an approach in testing the model using SEM. The findings has an implication to the realm of science in causality theories, and enrich the knowledge. Also this can be as a reference model for the further research. Beside, the result is useful for the practical managers especially the leader in DPRK Secretariat of Pidie Jaya. The variables related figure the points that need to be improved and strengthened for the better employee performance.

\section{REFERENCES}

Azwar, Darsono, N. and Djalil, M. A. (2017) 'Pengaruh Kepemimpinan Transformasional, Budaya Organisasi Dan Kompensasi Terhadap Prestasi Kerja Melalui Kepuasan Kerja Pegawai Kantor Kesyahbandaran Dan Otoritas Pelabuhan Malahayati Banda Aceh', International Journal of Social Science \& Economic Research, 2(7).

Bhuian, S. N. and Menguc, B. (2002) 'An extension and evaluation of job characteristics, organizational commitment and job satisfaction in an expatriate, guest worker, sales setting', Journal of Personal Selling and Sales Management, 22(1), pp. 1-11. doi: 10.1080/08853134.2002.10754288.

Boles, J. et al. (2007) 'The relationship of facets of salesperson job satisfaction with affective organizational commitment', Journal of Business and Industrial Marketing, 22(5), pp. 311-321. doi: 10.1108/08858620710773440.

Deshpandé, R., Farley, J. U. and Webster, F. E. (1993) 'Corporate Culture, Customer Orientation, and Innovativeness in Japanese Firms: A Quadrad Analysis', Journal of Marketing, 57(1), pp. 23-37. doi: 10.4135/9781452231426.n4.

Dessler, G. (2003) Manajemen Sumber Daya Manusia. Jakarta: PT Indeks.

Edirisooriya, W. A. (2014) 'Impact of Rewards on Employee Performance: With Special Reference to ElectriCo .', Proceedings of the 3rd International Conference on Management and Economics, (February), pp. 311-318.

Ferdinand, A. (2006) Metode Penelitian Manajemen Pedoman Penelitian untuk Penulisan Skripsi Tesis dan disertai Ilmu Manajemen, Semarang: Universitas Diponegoro. Semarang: Fakulas Ekonomi dan Bisnis Univ Diponegoro.

Furnham, A. et al. (2005) 'A cross-cultural investigation into the relationships between personality traits and work values', Journal of Psychology: Interdisciplinary and Applied, 139(1), pp. 5-32. doi: 10.3200/JRLP.139.1.5-32.

Hartati, I. (2005) 'Pengaruh Kesesuaian Kompetensi dan Motivasi Kerja terhadap Kinerja Pegawai pada Sekretariat Daerah Kabupatcn Malang', Jurnal Eksekutif, 2(1), pp. 63-80.

J. Peters, T. and H. Waterman, R. (1982) In Search of Excellence: Lessons From America's BestRun Companies. London: Harper Collins Business. doi: 10.2307/2393015.

Latan, H. and Ghozali, I. (2012) 'Partial Least Square: Konsep, Teknik, dan Aplikasi SmartPLS 


\section{International Journal of Business Management and Economic Review}

Vol. 3, No. 01; 2020

ISSN: 2581-4664

2.0 M3', Semarang: Badan Penerbit Universitas Diponogero.

Mangkunegara, A. A. A. P. (2010) Evaluasi Kinerja SDM. 2nd edn. Bandung: Refika Aditama.

Nawawi, H. (2011) Manajemen Sumber Daya Manusia Untuk Bisnis Yang Kompetitif. Yogyakarta: Gadjah Mada University Press.

Robbins, S. P. and Judge, T. A. (2012) Organizational Behavior. 15th edn. Edited by S. Yagan. San Diego: Pearson.

Schein, E. H. (1996) 'Three cultures of management: The key to organizational learning', Sloan Management Review, 38(1), pp. 9-20.

Shahzad, F. et al. (2012) 'Impact of Organizational Culture on Organizational Performance: An Overview', Interdisciplinary Journal Of Contemporary Research in Business, 3(9), pp. 975-985. doi: 10.1007/BF00310042.

Siagan, S. P. (2012) Manajemen Stratejik. Jakarta: PT. Bumi Aksara.

Soetrisno, E. (2009) MANAJEMEN SUMBER DAYA MANUSIA. Cetakan 9,. Jakarta: Kencana. Available at: https://books.google.co.id/books?id=OhZNDwAAQBAJ\&printsec=frontcover\&dq=inauth or:\%22Dr.+Edy+Soetrisno, + M.Si\%22\&hl=en\&sa=X\&ved=0ahUKEwjUlt6H0ODjAhVBrI 8KHQqZAGYQ6AEIKTAA\#v=onepage \&q\&f=false.

Sopiah (2008) Manajemen Sumber Daya Manusia. Jakarta: PT. Ghalia Indonesia.

Timpe, A. D. (2012) Seri Manajemen Sumber Daya Manusia 6: Kinerja = Performance. Edited by A. D. Ti. Jakarta: PT Elex Media Komputindo.

Wibowo (2013) Budaya Organisasi. Jakarta: Rajawali Pers.

William B. Werther, J. and Davis, K. (1996) Human Resources and Personnel Management. 5th Editio. New York: McGraw-Hill.

Yuniarsih, T. (2009) Manajemen Sumber Daya Manusia. Bandung: Alfabeta. 